\title{
An Ecocritical Reading of Ijala Chant: An Example of Ogundare Foyanmu’s Selected Ijala Chant
}

\author{
Olaniyan Solomon O. \\ University of Ibadan, Nigeria
}

\begin{abstract}
African artists demonstrate social commitment and sensibility in various ways as they create works that both sensitise and conscientise people in their milieu. Although ecocriticism itself is a relatively new theory, African artists have been preoccupied with issues bothering around environment in order to protect and preserve it. Ijala genre has been studied by different scholars such as Babalola S. A. (1966), Olukoju E. O. (1978) and Alagbe 'Sayo (2007) from diverse perspectives; however, its ecocritical relevance has not been investigated. It is in view of the foregoing that this paper carries out an ecocritical reading of Ijala chant: an example of Ogundare Foyanmu's selected Ijala chant. The paper aims at establishing environmental consciousness in the work of this oral artist. It is observed that though ecocritical theory itself is new in African literature, African artists have shown commitment towards environmental protection in their works from time immemorial. Foyanmu conscientises the people to desist from sneeringly underrating the effect of water hazard. The paper, therefore, has no doubt, established that the subject of Ijala genre is not in any way limited to hunting or hunters' life. It is also used to address other relevant socio-political and economic issues.
\end{abstract}

Keywords: Ijala, ecocriticism, environmental hazards, Foyanmu

Criticism worthy of its name arises from commitments deeper than professionalism

—Lawrence Buell (2005, p. 97)

\section{Introduction}

The history of literature is the history of the human race. This assertion is not unconnected with the general conception that literature is a microcosm of the macro-human world. Therefore, society (life) affects literature, since no literature exists in vacuum. Literature as a humanistic field of scholarship timely responds to the contemporary social happenings. Perhaps one of the social and utilitarian functions of literature is the betterment of the human society. Literary artists have a way of responding to the pressing contemporaneous issues. Globally, environmental challenges are rampant. Most times, in a bid to beautify his environment, man ends up destroying it and invariably destroying himself.

When there is no problem people do not think of solution. Hence, the birth and emergence of ecocriticism presupposes the existence of ecological challenges. Ecocriticism as a literary concept emerged from the discussions and meetings of the WLA (the Western Literature Association), a body whose field of interest is the

Olaniyan Solomon O., master, Department of English, University of Ibadan. 
literature of the American West (Barry, 1995).

\section{Ecocriticism: Emergence and Meaning}

The word ecocriticism is a semi-neologism. Eco is the shortened form of ecology, which is concerned with the relationships between living organisms in their natural environment as well as their relationships with that environment. By analogy, ecocriticism is concerned with the relationships between literature and environment or how man's relationships with his physical environment are reflected in literature. These are obviously interdisciplinary studies, unusual as a combination of a natural science and a humanistic discipline. The domain of ecocriticism is very broad because it is not limited to any literary genre. The most widely known ecocritics are Lawrence Buell, Cheryll Glotfelty, Simon C. Estok, Harold Fromm, William Howarth, William Rueckert, Suellen Campbell, Michael P. Branch and Glen A. Love. Glotfelty (1996) writes: "ecocriticism is the study of the relationship between literature and the physical environment" (p. xviii). Ecocriticism, in fact instigates a call to literature to connect to the issues of today's environmental crisis. Thus, ecocriticism is directly preoccupied with both nature (natural landscape) and the environment (landscape both natural and urban) (Serpil Oppermann, 1999).

According to Childs and Fowler (2006), the emergence of ecocriticism occurred in the half of the twentieth century, "when after centuries of systematic exploitation, many of those non-renewable resources were nearing the point of exhaustion” (p. 78). In his opinion, Barry (1995) asserts that ecocriticism is an emergent movement which began in America in the late 1980; while it emerged in Britain in the early 1990. In the same vein, Lawrence Buell (2005) expresses his surprise on the late arrival of such an important theory as ecocriticism:

At first sight, the belatedness and liminality of the recent environmental turn in literary-critical studies seems strange. For creative art and critical reflection have always taken a keen interest in how the material world is engaged, absorbed, and reshaped by theory, imagination, and techne. Humankind's earliest stories are of earth's creation, of its transformation by gods or by human ingenuity's “second nature”, as Cicero first called it - tales that frame environmental ethics in varied ways. In at least one case they may have significantly influenced the course of world history. (p. 12)

Here, Buell is of the position that this literary theory ought to have been given birth to before now considering the various environmental issues literature has addressed over the years.

Heise (1997) is of the opinion that the story of the institutional formation of ecocriticism has been told in detail and from several perspectives, scattered projects and publications involving the connection between literature and the en-vironment in the 1980s led to the founding of ASLE, the Association for the Study of Literature and the Environment, during a conven-tion of the Western Literature Association in 1992.

In the same vein, Hutchings (2007) posits:

As a field of literary inquiry, ecological criticism—or "ecocriticism”, as it is now commonly known—investigates literature in relation to the histories of ecological or environmentalist thought, ethics, and activism. One of ecocriticism's basic premises is that literature both reflects and helps to shape human responses to the natural environment. By studying the representation of the physical world in literary texts and in the social contexts of their production, ecocriticism attempts to account for attitudes and practices that have contributed to modern-day ecological problems, while at the same time investigating alternative modes of thought and behaviour, including sustainable practices that would respect the perceived rights or values associated with non-human creatures and ecological processes. (p. 1)

Hutchings (2007), in the foregoing excerpt, foregrounds the mimetic nature of literature; this theory is a response to the transformational steps taken by man to modify the natural environment. Eco-criticism therefore, 
reacts to the gamut of ecological problems ravaging the universe in the present-day world. Meanwhile, the late emergence and development of this critical theory does not indicate that writers have maintained silence over environmental issue. For instance, the British Romantic poetry is preoccupied with several issues bothering around nature. For instance, just as the Francophone negritudinist obsessively engulfed in love for African natural environment, Romantic poets such as William Wordsworth, John Keats and Samuel Taylor Coleridge, passionately emphasise the beauty, permanence, innocence, and many other thematic preoccupations revolving natural environment.

Moreover, it should be noted that Africans are also on the red alert to issues affecting their physical environment. The origin of ecocriticism, therefore, should not be politicised and hegemonised by domineering colonialist discourse. This goes in line with Rob Nixon's (2007) challenge of the exclusion of the names of the foremost ecocritics from Africa. He refers to Jay Parini, who published an essay titled "The Greening of the Humanities” as not only myopic, but also incomplete and not well-researched. The reason for this is because while Parini lists the names of the ecocritics, he consciously excludes the name of the foremost ecocritic, ecoactivist and ecological martyr, Ken Saro-Wiwa. Nixon (2007) maintains:

This unselfconscious parochialism was disturbing, not least because at that time I was active in the campaign to release Ken Saro-Wiwa, the Ogoni author held prisoner without trial from his environmental and human rights activism in Nigeria. Two weeks after Parini's article appeared, the Abacha regime executed Saro-Wiwa, making him Africa's most visible environmental martyr... yet, clearly, Saro-Wiwa's writings were unlikely to find a home in the kind of environmental literary lineage outlined by Parini. (p. 715)

By and large, the point of the argument above is that it is not the Western world that taught Africans on how to respond to nature-related issues. Every normal human being must be able to respond to his natural environment. William Slaymaker (2007) posits:

Black African critics and writers have traditionally embraced nature writing, land issues, and landscape themes that are pertinent to national and local cultural claims and that also function as pastoral reminiscence or even projections of a golden age when many of the environmental evils resulting from colonialism and the exploitation of indigenous resources have been remediated. (p. 683)

For instance, African writers especially those from the East have variously addressed issues relating to land seizure. Examples of such writers are Ngugi wa Thiong'O of Kenya and Ibrahim Hussein of Tanzania. These, through the beatification of the Mau Mau and Maji Maji insurrection have decried imperialism. The reason for this is because of the high value Africans attach to land. Land represents the connection between the world of the living and that of the dead. It is like cultural birth-right that must not be taken away.

As a matter of fact, therefore, African artists (whether oral or written) have devoted their art towards saving their environment from destructive tendencies even before the official inauguration of eco-criticism. For instance, Foyanmu's selected chant for this work was performed as far back as 1980, while ecocriticism was inaugurated in America in the late 1980 and emerged in Britain in the early 1990. The point being made here is Africans were never taught by the Europeans how to preserve their eco-system.

\section{Ogundare Foyanmu as Ijala Chanter}

Born in 1936, in Ogbomoso, Nigeria, Ogundare Foyanmu learnt Ijala by imitation from his uncle, whose 
passion for chanting Ijala cannot be overemphasised. Foyanmu did not have any academic certificate; he, however, learnt writing and reading through the Adult Education Literacy classes organised by Ogbomoso local government of Oyo State.

Foyanmu lost his parents at the tender age, which made him stay with his uncle. Foyanmu did not hesitate to make judicious use of the opportunity he had during the time while he was with his uncle. Thus, his stay with his uncle was full of adventure as he used to accompany group of hunters to hunting safari, after which they would gather at night to entertain one another with Ijala. Foyanmu started having strange dreams, as he always found himself chanting in his dream to some group of hunters. He later informed his uncle of his dreams, who accurately interpreted the dreams to mean that he (Foyanmu) would later become a prolific Ijala chanter. He was encouraged by his uncle's interpretation of his dreams. Thus, he started working towards fulfilling the dreams until the death of his uncle (Alagbe, 2006).

Ogundare Foyanmu started his performance by attending outings though not necessarily on invitation. He was always welcomed by the celebrants of various occasions. Initially, he had to restrict his performances to Ogbomoso Township. This was peradventure due to his relatively little exposure. He received monetary and material rewards whenever he performed.

Foyanmu, today, has become a household name; this is not, however, unconnected with his creative feat in Ijala.

Yoruba literature is replete with plethora of oral genres, one of which is Ijala. The art of Ijala is said to have originated from Ogun (the God of Iron) who has dualistic attribute in the sense that it is both creative and destructive (Babalola, 1966). Hence, it is represented by Iron. Ogun was said to have commanded all the hunters to sing his epideitic name (oratory) to commemorate his "big fight" (Ija nla) with Aparo whose fault was that he could not get palm wine to drink when he descended from the top of the hill where he was, to look for palm wine in a town around Iree, a town in the present day Osun State, Nigeria. In other words, Ijala is chanted in honour of Ogun amidst the consumption of a great volume of palm wine (Babalola, 1966).

Among the Yoruba people of Nigeria, Ijala is a performatory oral genre mainly by the hunters, usually after a hunting expedition or when a prolific hunter answers divine call. Foyanmu's Ijala art focuses on several humanistic subjects such as culture, politics, leadership, family, and environment.

\section{An Ecocritical Reading of Foyanmu’s “Omíyalé” (Flood)}

The poet begins this chant on a lugubrious mood as he recounts the havoc of the Ibadan historic 1980 flooding which claimed many lives and swept away unquantifiable properties. Foyanmu (1980) asks:

\footnotetext{
Ojo odun yii o paye run ni?

O gboko gbeyawo

O tun gbomo lo.

Will this year rain destroy the world?

It swept the husband and wife

And also swept away the child.
}

This attests to destructive havoc the rain has caused humans. This particular rain could be likened to the biblical account of flood through which God destroyed the world because of sin. Though rain is armless, is could 
be dangerously harmful. Its effect on the family cannot even be described with words, or what can one say when a whole family is swept away through flooding.

Among those affected by the life-claiming rain included pregnant women, newly married couples, nursing mothers and those at their various places of work.

For rain to have carried human beings, it must have carted away several non-living things. In other words, it is not only humans that are carried away; even properties worth huge sum of money are lost to the flooding.

According to Foyanmu (1980):

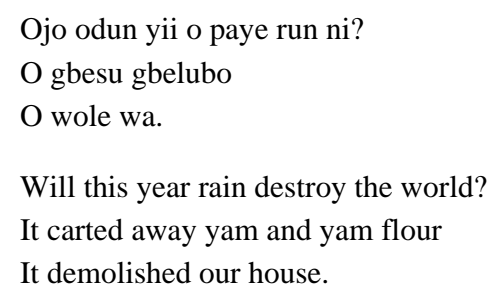

Adedeji, Odufuwa, and Adebayo (2012), lend credence to the fact that flood disasters have led to economic losses and loss of lives:

In the past four decades, economic losses due to natural hazards such as, floods disasters have increased in folds and have also resulted in major loss of human lives and livelihoods, the destruction of economic and social infrastructure, as well as environmental damages during this period. (p. 45)

Although flooding is a natural disaster, man cannot be completely exonerated from its occurrence. Human actions or inactions contribute immensely to the management and damage of the environment. One major cause of environmental disaster is man's contemptuous (mal)treatment of nature. In other words, human beings usually underrate the effect of ecological degradation. Foyanmu (1980) chants:

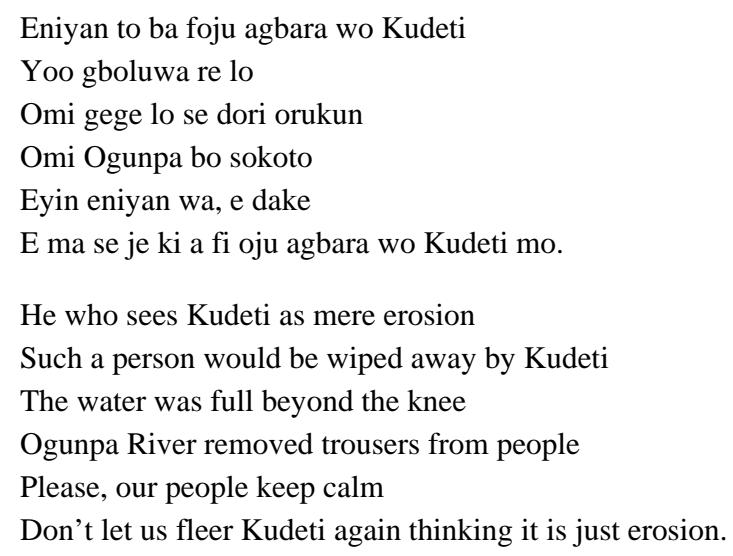

As portrayed in the foregoing, the artist-chanter sensitises and consceintises the people to stop underrating the consequential effect of erosion. The reason for this admonition is because little erosion, if not timely checked and controlled, can escalate to disastrous flood. Both Kudeti and Ogunpa are popular rivers in Ibadan. According to Nfah-Abbenyi (2007, p. 711), projects should be "planned in such a way that the ecology is taken into consideration every step of the way”. Without prevarication, the planlessness of some building constructions in the contemporary society is responsible for incessant flooding which has become the order of the day lately. 
Foyanmu (1980) goes further to enumerate salient human haphazard (in)actions that snowball into environmental hazards:

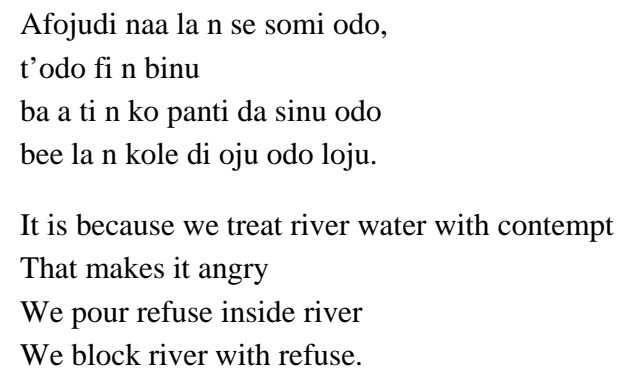

Ibadan city is historically known for its notoriety in dirtiness. The above excerpt foregrounds why the city remains dirty. Whenever rain falls, people bring out their dustbins to pour inside the flowing water. This would eventually lead to the blockage of drainage and consequently prevent free flow of water. Niyi Osundare (1986), a renowned eco-activist-poet, writes in favour of earth:

Ours to work not to waste

Ours to man not to maim

This earth is ours to plough, not to plunder. (The Eye of the Earth, p. 49)

Man's activities in Foyanmu's chant are nothing but that of wasting, maiming and plundering of earth which is supposed to be prosperously worked, properly manned and protectively ploughed.

Despite the fact that human beings have repeatedly experienced flood disasters through their unconscious and thoughtless abuse of flora and fauna, their stubbornness has not been curtailed just like that of a goat. While various governmental and non-governmental agencies have created awareness to sensitise people on the need to protect and preserve their environment, all these awareness campaigns seem to fall on deaf ears. Though it is often said that experience is the best teacher, the veracity of this universal assertion and aphorism is not without doubt. This position is not unconnected with people's persistent downgrading, damaging and maltreating of ecosystem. The same people that lost relations through flood in the previous year would still be seen pouring refuse inside drainage. Even the most stubborn goat does remember the pain it sustained as a result of its wanton disobedience. Man, therefore, has not learnt from all his ugly experiences.

This Ijala chanter compares water with fire so as to establish the reason for man's sneering of water:

Gbogbo afojudi ta n se sodo yii

To ba se ina ni ko ni i gba

Gbogbo wa la mo pe ara ina ko gba arifin

Ara odo lo gbegbin

Ara ina ko awada, o ko arifin

Omi odo lo gba gbere. (Foyanmu, 1980)

All our contempt for river

If it were to be fire, it would not condone it

All of us know that fire does not tolerate sneer

It is only the river that can bear contempt

Fire abnegates disdain, it disapproves fleer

It is the river water that can be scorned. 
This lends credence to the fact that human beings naturally fear fire and so, do away with anything that may cause its accident/disaster. However, water is sneeringly treated. Contrary to what Foyanmu says, river water cannot be eternally abused as it would "fight back" one day. Although fire "retaliates" immediately, water may delay its own effect; this does not, however, mean that the consequence of man's unwholesome activities would not be felt sooner or later.

Foyanmu (1980) specifically makes a historical allusion to the flood which plagued the largest city in Africa, Ibadan, on Sunday, the 31st August, 1980. This historic flood disaster affected many lives and unquantifiable amount of properties:

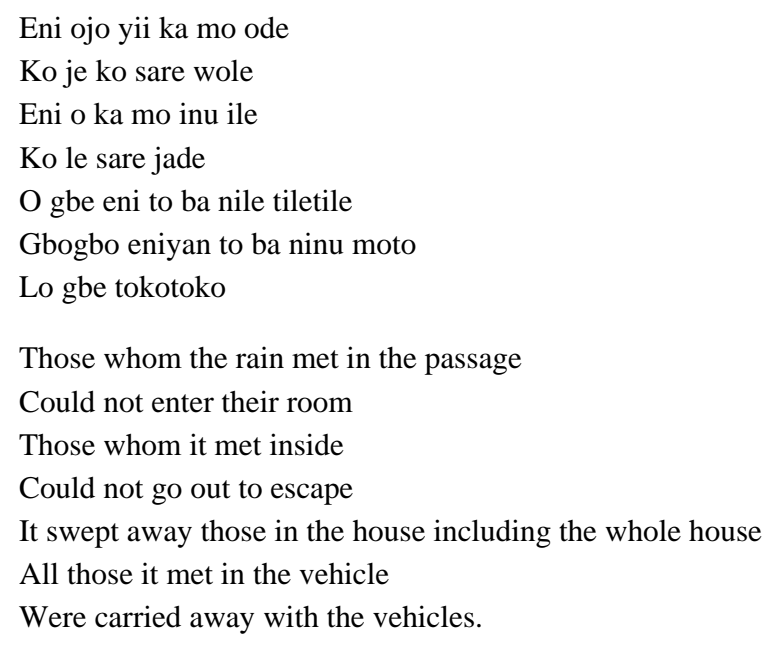

Although water does not have hands, it is capable of carrying away objects that are even heavier than it does. The above shows the painful and lugubrious effects of flood on man and his environment, which are characterised by loss of life and property.

Moreover, the poet pinpoints various categories of people that were affected by Ibadan flood of 1980:

Bi ti n gbolowo towo-towo

Bee ni n gbe eni ti n sowo ajapa teru teru

Obinrin to gbe toyun-toyun ko kere

Alabiamo to gbe tomotomo ko lonka

Atawon egbe bi ore

Bi i gbajumo bi i iyekan

Atokunirn atobinrin

Atewe atagba, atonile atalejo. (Foyanmu, 1980)

As it carried the rich with their riches

So it carried those who sell tortoise with their loads

Pregnant women that it carried away were without number

Nursing mothers that it carried away with children could not be counted

Including clubs of friends

Like important dignitaries and relations

Both male and female

Young, old, natives and foreigners.

What this means is that environmental disaster does not recognise sex, race, tribe, social class, and status. No 
one is exempted from the painful pangs of hazards caused by man's mistreatment of his God-given environment. Also, it is not only the poor that are fond of polluting the surrounding by dumping refuse inside drainages. Both the rich and the poor play negative roles in ecological degradation. For instance, the rich use their affluence in constructing companies and industries which later result into deforestation and pollution (land, air, and water). Thus, neither the rich nor the poor can be exonerated in sneering (under)use of natural resources.

Foyanmu has been able to respond to the global ecological crisis and address important environmental issues, specifically by examining values, in literary texts, with deep ecological implications. Ecocriticism, then, takes an earth-centered approach to literature, and an ecological approach to literary criticism. Ecocriticism mainly concentrates on how literature interacts with and participates in the entire ecosphere (Oppermann, 1999).

In addition, the grievous repercussion of flood disaster is beyond description as it severs familial relationship when many people such as children, mothers, fathers, and even newly wedded couples are swept away through the flood. No doubt, "flood is a rain of sorrow" as Foyanmu chants; although the "sorrow" is not without a cause. In the same vein, the flood disaster rendered many people homeless and property-less as landlords become tenants in camps.

To forestall future occurrence, Foyanmu (1980), among other things, advocates prayer, since "there is no situation that is too big that cannot be surmounted by prayer". Although nothing is wrong with prayer itself, man should learn to stop destroying himself through the abuse of environment. No amount of praying can prevent environmental hazards if people keep on preying on the ecosystem. When human beings engage in acts that are capable of destroying their natural surroundings, they can be likened to the proverbial hen that defecates inside the pot-its own grave.

Foyanmu (1980), a conscience of his people, is not unaware of the politics of corruption and red-tapism which has ravaged the polity. Following the Ibadan 1980 flood, many humanitarian donors contributed both pecuniary and material resources towards alleviating the sufferings of the victims. The poet notices unnecessary delay in the disbursement of the funds:

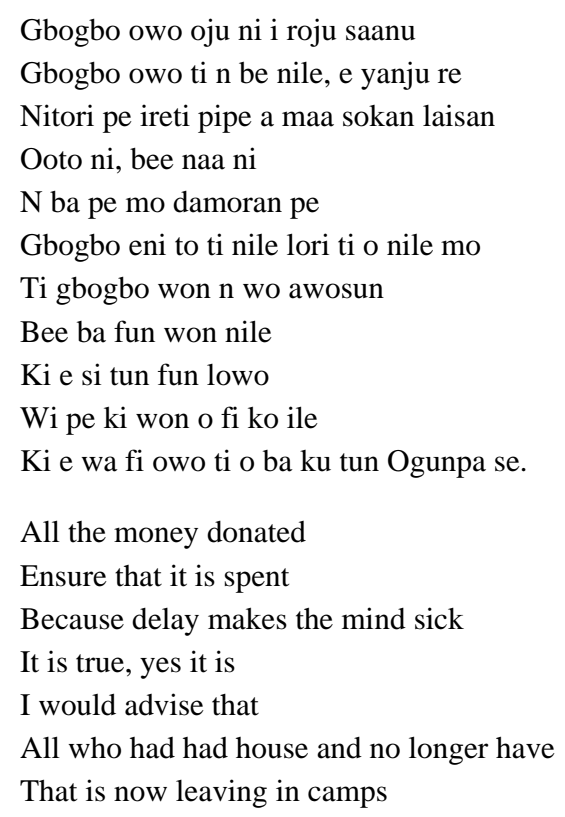


If they are given land

They should also be given money

That they would use to build

And use the remaining money to construct Ogunpa.

The foregoing is an indication of unnecessary bureaucracy in the execution and proper utilisation of donors' contribution. It is unfortunate that on several occasions when it is planned perhaps by the government to alleviate masses' suffering, it ends up aggravating it by non-visionary, myopic, corrupt, irresponsible, and kleptomaniac people that are saddled with the responsibility of disbursing such resources. For instance, it is widely reported in the national dailies that when in 2012 flood disaster bedevilled some states, people wailed and cried out for assistance that would cushion their sufferings. It was not, however, long when government and some philanthropists positively responded by releasing and donating funds. Nevertheless, the story has changed today as the funds have been diverted into the personal pockets of those put in charge of the disbursement. The suffering people, therefore, become victims of natural disaster and leadership failure. Hence, they are left in a state of perennial disillusionment. Osundare (1986), in his poem titled “They Too Are the Earth”, advocates the need for justice:

They too are the earth the swan songs of

Beggars sprawled out in brimming gutters

... the distance groans of thousand

Buried alive in hand, unfathomable mine.... (The Eye of the Earth, p. 48)

Instead of cushioning the groaning of the poor victims of ecological problems, leaders only aggravate their pains by siphoning the funds meant for their relief.

Foyanmu, through this chant has no doubt lent his voice to environmental consciousness. Slaymaker (2001) posits that black African critics, writers and even oral artists

Have traditionally embraced nature writing, land issues and landscape themes that are pertinent to national and local cultural claims and that also function as pastoral reminiscences or even projections of a golden age when many of the environmental evils resulting from colonialism and exploitation of indigenous resources have been remediated. (p. 684)

In other words, African artists do not need to be sensitised and taught by Euro-ecocritics before they create ecological awareness through the weaponry of their literary creations. However, despite the fact that African artists are "traditionally" ecocentric, conscientising the society to preserve environment, the people are persistently non-sensitive to environmental disasters. Ecocritics like Foyanmu have relentlessly sermonised the mission statement of ecocriticism which is to preserve nature everywhere man finds himself.

\section{Conclusions}

Foyanmu rises to the challenge to awaken the ecological consciousness of the populace to environmental-related contemporary problems and charge them to maintain cleanliness. The quintessence of artist's conscientisation is to save mankind from natural disasters which may be prevented and also to rescue human environment from wanton degradation, pollution and abuse.

\section{References}


Adedeji, O. H., Odufuwa, B. O., \& Adebayo, O. H. (2012). Building capabilities for flood disaster and hazard preparedness and risk reduction in Nigeria: Need for spatial planning and land management. Journal of Sustainable Development in Africa, 14(1), 45-58.

Alagbe, S. (2006). Ogundare Foyanmu: Ijinle ede ohun enu yoruba. Astra-J Creations: Ogbomoso.

Babalola, A. (1966). The content and form of Yoruba Ijala. Oxford: Oxford University Press.

Barry, P. (1995). Beginning theory: An introduction to literary and cultural theory. Manchester: Manchester University Press.

Buell, L. (1999). The ecocritical insurgency. New Literary History, 30 (summer), 699-712.

Buell, L. (2005). The future of environmental criticism: Environmental crisis and literary imagination. Oxford: Blackwell Publishing.

Buell, L. 1995. The environmental imagination: Thoreau, nature writing, and the formation of American culture. Cambridge, MA: Harvard University Press.

Childs, P., \& Fowler, R. (2006). The Routledge dictionary of literary terms. London and New York: Routledge.

Foyanmu, O. (1980). Omiyale Vol.7. ORCLP 120 [Audio CD]. Ibadan: Olatunbosun Records Company.

Glotfelty, C., \& Fromm, H. (Eds.). (1996). The ecocriticism reader: Landmarks in literary ecology. Athens, Georgia and London: The University of Georgia Press.

Heise, U. (1997). Science and ecocriticism. American Book Review, 18(August), 4-6.

Hutchings, K. (2007). Ecocriticism in British romantic studies. Literature Compass, 4(1), 172-202.

Nfah-Abbenyi, J. M. (2007). Ecological postcolonialism in African women’s literature. In T. Olaniyan, \& A. Quayson (Eds.), African literature: An anthology of criticism and theory (pp. 707-714). Oxford: Blackwell Publishing.

Nixon, R. (2007). Environmentalism and poscolonialism. In T. Olaniyan, \& A. Quayson (Eds.), African Literature: An Anthology of Criticism and Theory (pp. 715-723). Oxford: Blackwell Publishing.

Oppermann, S. (1999). Ecocriticism: Natural world in the literary viewfinder. Journal of Faculty of Letters, 16(2), 29-46.

Osundare, N. (1986). The eye of the earth. Nigeria: Heinemann Educational Books.

Slaymaker, W. (2007). Ecoing the other(s): The call of global green and black African responses. In T. Olaniyan, \& A. Quayson (Eds.), African literature: An anthology of criticism and theory (pp. 683-697). Oxford: Blackwell Publishing. 